\title{
Institutional Impacts on Choice of Traditional Agroforestry-Based Rural Community Livelihood Strategies in Maluku (Utilization of "Dusung" and Nutmeg in Booi Village, Maluku)
}

\section{Hendri Dony Hahury ${ }^{1 *}$, Titi Susilowati Prabawa ${ }^{2}$, Pamerdi Giri Wiloso', Tontji Soumokil ${ }^{2}$, Marthen Luther Ndoen ${ }^{2}$}

\author{
${ }^{1}$ Department of Economic Development, Faculty of Economics and Business, Pattimura University, Jln. Ir. M. Putuhena, \\ Kampus Poka, Ambon, Indonesia, 97233 \\ ${ }^{2}$ Development Studies of Interdisciplinary Faculty, Satya Wacana Christian University, \\ Jl. Diponegoro No. 5260, Salatiga, Indonesia 50711
}

Received January 23, 2020/Accepted July 29, 2020

\begin{abstract}
The ability of rural communities responding to vulnerabilities highly depends on local and institutional adaptations. The institutional adaptation is formed based on habits rooted in the community's local knowledge and life experience. Utilization of traditional agroforestry on rural land is unique for each individual, resulting different livelihood strategies to deal with vulnerability. This study aims to understand institutional impacts on the choice of rural livelihood strategies through traditional agroforestry using an institutional approach (traditions, customs, and rules) and a livelihood framework. This research was conducted in Booi Village, Maluku, from October 2016 to September 2018. The data was collected through in-depth interviews and document studies. Interviews were conducted to key informants such as Raja (head) of Booi Village, farmers (landowners), community members who did not own land, and village governments. The results showed that the community had a variety of choices for livelihood strategies, including intensification, extensification, diversification, and "holding" nutmeg seeds. The presence of institutional impact was also proven to have a significant effect on the livelihoods of the Booi community, for example, in the form of access for the community who did not have assets (informal insurance).
\end{abstract}

Keywords: institutional, choice oflivelihood strategy, dusung, nutmeg tree

*Correspondence author, email: hahury31@gmail.com

\section{Introduction}

The perspective of economics (neo-classical) is still debating the availability of land as a resource that is physically available, fixed, and limited. In this context, mainstream economists only view land as a tangible asset, while the old institutional economist sees resources as something functional and dynamic (Nugrohowardhani, 2016). In other words, the use of plantation resources in the form of traditional agroforestry does not only affect the household economic aspects of rural communities but also social and cultural aspects based on their local knowledge and experience (Jose, 2009; Martin et al., 2016).

This study aims to understand the institutional impacts of traditional agroforestry-based livelihood strategies in rural areas in the form of the use of dusung and nutmeg trees. In Maluku, traditional agroforestry is known as "dusung/dusun" which has been rooted in the community, especially in Central Maluku. Dusung is a valuable intangible asset and included in indigenous knowledge and technology that has adapted to environment and local communities (Wattimena, 2003). This plantation activity acts as an economic driver and aims to improve the living standard of local communities (Muttaqin, 2013). However, in the utilization of these resources, there were poor communities with limited access to resources (Wollenberg et al., 2004; Contreras \& Fay, 2005; Miettinen et al., 2011). In addition, poor ownership rights, lack of stakeholder support, and poor institutional performance have still persisted, leading to poor resource management (Napitu et al., 2017).

This study locates in Booi Village, Maluku, which is categorized as one of the least developed villages in Indonesia (KPDT, 2017). This reality is disproportionate with the 31.4 ha of land owned by Booi Village, in which 13 ha of it was used for nutmeg trees. Table 1 presents the type of trees found in Booi Village.

In 2018, Booi Village's population is 914 people (BPS Maluku Tengah, 2018) with majority work as armer. Their primary source of household income is from nutmegs. Table 2 shows different types of occupation/work of Booi Village community.

Various data shown earlier indicate that Booi Village community lives under poverty line, made them vulnerable 
Table 1 Type of trees in Booi Village

\begin{tabular}{lc}
\hline Type of tree & Area (ha) \\
\hline Cloves & 7.9 \\
Nutmeg & 13 \\
Walnuts & 6 \\
Coconut & 1.5 \\
Sago & 1 \\
Mango & 2 \\
\hline Total area & 31.4 \\
\hline Source: Statistics of Booi Village (2018)
\end{tabular}

to livelihood uncertainty. The livelihood uncertainty was a result of changes in social, economic, and even government policies (Mehta et al., 1999; Budiono et al., 2018). Studies of changes and risks show that the community was able to meet these challenges through local adaptation. While the effectiveness depended on local institutionalism, such as norms, formal and informal policies, which also influenced the way individuals, households, and communities responded to pressure and risk (Young \& Solbrig, 1992; Kherallah \& Kirsten, 2001).

From the perspective of "ekonomi kelembagaan lama" or "old institutional economy" (EKL/IOE), institutions are not only limited to individual actions but the embodiment of thinking and behaving in society (Rutherford, 2001). In other words, institutionalism is formed based on habits rooted in the community's local knowledge and life experiences, including the use of dusung in Booi Village. A study by Berkes et al. (2000) showed that local knowledge on community awareness of natural environment is called traditional ecological knowledge. For this reason, the local community knowledge can be seen through their habits and daily behavior. Institutionalism in Booi Village is reflected in customs, rules, and livelihood diversification, including diversification of livelihoods and farming, as well as local institutional characteristics as a form of community livelihood strategy. In this context, institutionalism (habits and rules) acts to reduce uncertainty or vulnerability through the regulation of interactions between individuals (North, 1990).

The livelihood strategy is related to how to manage or combine various livelihood assets to maintain or improve livelihoods (Peng et al., 2016). Yizengaw et al. (2015) showed that rural households in East Gojjam Zone, Ethiopia, had practiced diverse livelihood strategies by combining activities inside and outside agricultural sector for better household life. Meanwhile, in West Bengal, India, farmers in the countryside diversified their livelihoods by involving all family members. This livelihood diversification had a significant contribution for increasing household income (Saha \& Bahal, 2016).

The livelihood strategies in rural communities were applied differently depending on the available livelihood resources or assets, and vulnerabilitie circumstances (Wulandari, 2017). In research in rural Mozambique Africa, Walelign (2016) found that the lives of poor farmers in rural areas were very dependent on agricultural land as their livelihood assets. The same thing was also found in Central Nepal, where agricultural land owned by rural farmers was a major determinant of household access to livelihood
Table 2 Level of tree production in Dusung of Booi Village community

\begin{tabular}{lc}
\hline \multicolumn{1}{c}{ Type of tree } & Production $\left(\right.$ ton year $^{-1}$ ) \\
\hline Clove & 5.63 \\
Walnut & 4.80 \\
Coconut & 5.63 \\
Sago & 0.75 \\
Mango & 3.10 \\
\hline \multicolumn{2}{c}{ Source: Statistics of Booi Village (2018) }
\end{tabular}

strategies when shocks occurred (Khatiwada et al., 2017). Limited access to assets, in the form of agricultural land or plantations, is still a fundamental problem in rural communities, including in Indonesia. The agroforestry technique was used by rural communities in Gunung Kidul, Yogyakarta, as a livelihood strategy to meet their daily needs. A diversification strategy was chosen in the use of forests by combining various types of trees - either forestry, plantation, and agriculture, so that the results of these trees could be regulated while spreading risks in forest use (Oktalina et al., 2015). The spread of risk in this context was intended as a way to avoid economic losses if one type of trees could not meet household needs.

The various studies above show that rural communities have a way of dealing with vulnerabilities that endanger their livelihoods by employing various strategies, such as utilizing agricultural land and optimizing the existence of family members as a new source of income. However, these studies have not yet demonstrated the extent of institutional impact on the choice of rural livelihood strategies through the use of plantation land as traditional agroforestry. This study is expected to contribute to research on household livelihood strategies in rural communities, which so far have only focused on increasing income.

This article is based on empirical research in Booi Village, Saparua Island, Central Maluku. The main livelihood of the Booi Village community is gardening, and their household source of income is nutmeg. As a customary village, the behavior of the Booi Village community is regulated based on tradition, culture, and customs. Not all community members have access to assets because of the inheritance provisions of plantation land for boys based on patrilineal lineage. It gets worse by a rapid increase in population, increasing variety of life needs, and selling price of nutmeg (seeds and fruits), which leads to uncertainty.

Based on these descriptions, the research questions are: a) what institutionalism does the Booi Village community have regarding the use of dusung and nutmeg trees?, b) what are the choices of livelihood strategies of the community in dealing with vulnerability?, c) does the institutionalism owned by the community affect their livelihood sustainability?

\section{Methods}

To understand the institutional impact (traditions, habits, and rules) on the choice of livelihood strategies developed in the Booi Village community, the researchers used the livelihood framework presented in a study by Ellis (2000) (Figure 1). 
The livelihood framework in Figure 1 provides a way of thinking about the livelihoods of people who are considered marginal and poor. The framework views the community in certain conditions, such as vulnerability and crisis, to have impacts on their well-being. In this context, the Booi community tried to use the institutions (customary rules) that they had for dealing with vulnerability as an effort (strategy) to maintain their livelihoods. They relied on diverse livelihood assets, such as natural and environmental resources, social capital, and human resources. In its development, these livelihood assets were often modified by the role of social relations (such as kinship, religion, or race), institutional influences (such as rules, customs, and habits), and organizations (such as church/mosque, government, NGOs) as a result of the emergence of vulnerabilities (such as economic crises, volatile prices, disasters, and population growth). For this reason, the achievements of rural livelihood strategies would be in the form of "livelihood security" and "sustainability" such as the availability of stable household income.

This research was conducted qualitatively with ethnographic techniques that focused on holistic cultural studies of social groups (Chariri, 2009) to illustrate the institutional impact (rules, habits, and traditions) on the choice of livelihood strategies through the use of nutmeg plants and dusung as traditional agroforestry. The institutional impact on the choice of livelihood strategies was the construction of local communities (social constructed reality) that took place in certain environmental settings (Chariri, 2009). Thus, the paradigm underlying this research is the interpretive paradigm. The researchers tried to understand the subjects' framework by emphasizing the interpretation of meaning conveyed by the informants and not the assumptions of other researchers in existing literature (Chariri, 2009).

This research was conducted from October 2016 to September 2018 in Booi Village, Saparua Island, Central Maluku Regency, Maluku Province (Figure 2). The Booi Village was chosen as the research location for several reasons. First, it is one of the largest nutmeg producing centers on Saparua Island (Table 3) (Salampessy et al., 2012). Second, their main source of livelihood is farming with main household income is nutmeg plants.

Before collecting data, the researchers made initial observations regarding location, research permission, and knowledge of the norms, customs, habits, and languages

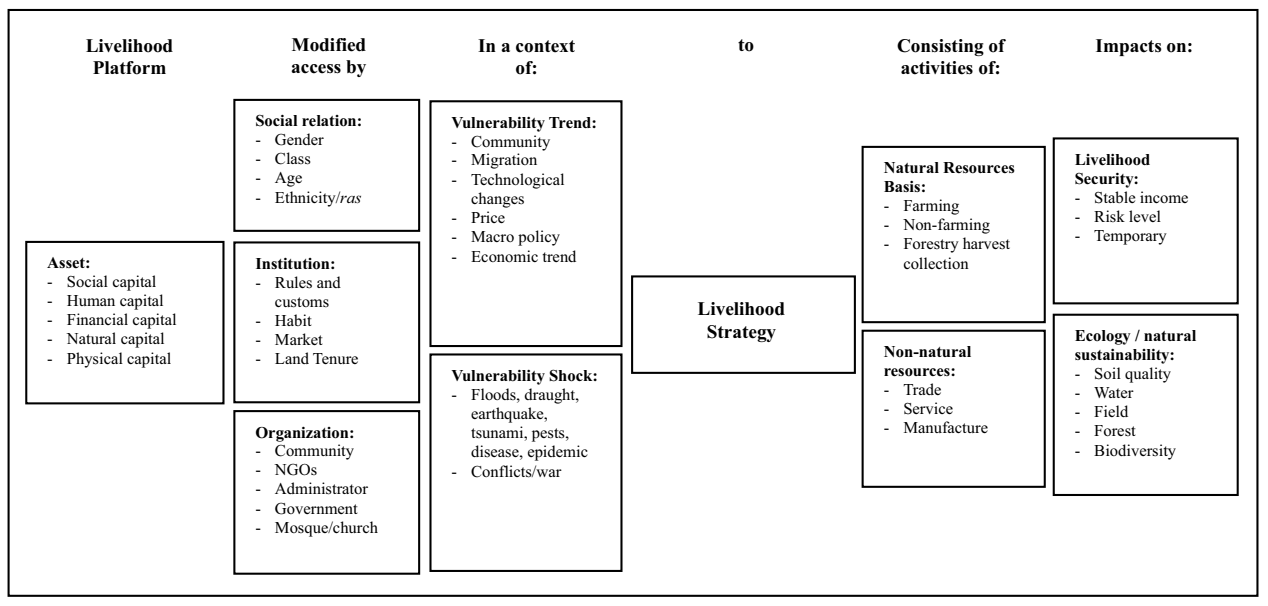

Figure 1 Livelihoods framework, Ellis (2000).

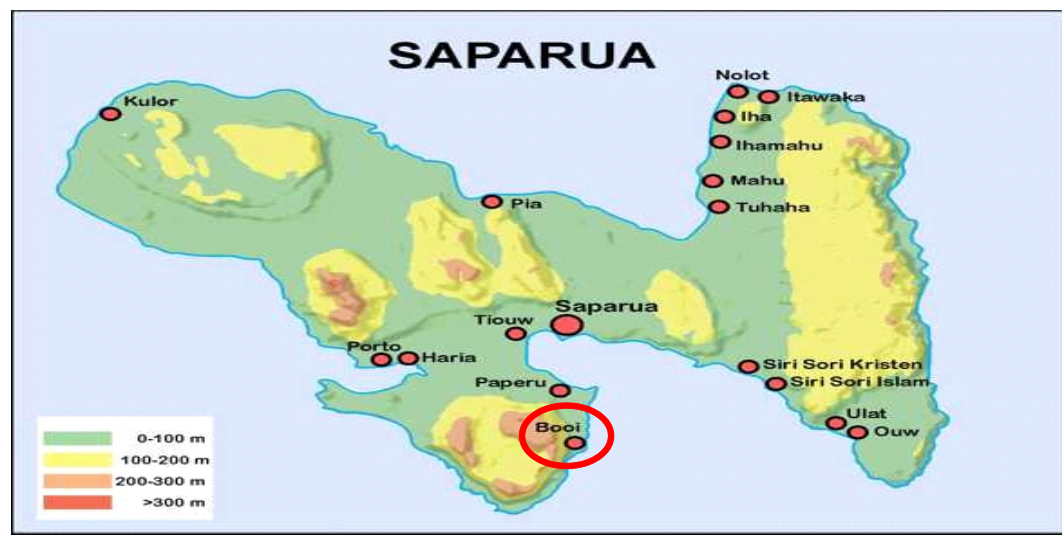

Figure 2 Map of research location. 
used by the Booi Village community. There were several stages taken by the researchers: 1) understanding the social/cultural system - at this stage, the researchers made contact with community members, especially community leaders, traditional leaders, and Booi saniri negeri (village government bodies) who had an influence and role as intermediaries in understanding the way of the Booi Village community live; 2) understanding their way to live - at this stage, the researcher tried to explore community's perspective towards people outside the community as well as what should be and not be done; and 3) adjusting to the environment of the Booi Village community - to capture the Booi Village community's view of life. The researchers adapted to the Booi community at the social, cultural, and customary levels.

After conducting the initial observations, data were then collected through in-depth interviews, observations, and documentation. In total, there were 11 informants involved. They were selected based on specific characteristics using purposive sampling technique to meet research objectives (Creswell, 2010). First, the informants should have good knowledge or understand the traditions and customs of the use of nutmeg plants and dusung through the enculturation process so that these traditions and customs were not only understood but also lived. Second, the informants should still be actively utilizing nutmeg plants and dusung as a source of household livelihood. The informants were categorized into two groups: key informants and informants with certain characteristics. The key informant group consisted of informants who were directly involved in the social interactions under the study. They included farmers (dusung owners) and Booi Village community members (dusung users). While the second group, the informants with certain characteristics, included Raja (village head), traditional leaders, and community leaders. They played a role when a data triangulation was conducted to compare observations with interviews, what was said publicly with what was said privately, and the results of interviews with existing documents. The researchers also then conducted a focus group discussion (FGD) by involving stakeholders, such as Raja, Saniri Negeri, traditional leaders, and community leaders with the aim of obtaining valid information. In addition, the researchers also accidentally met a dusung user from outside the Booi Village who illegally collected nutmeg seeds in the petuanan (customary land) of Booi Village. Table 4 presents the list of the informants involved.

The data were analyzed during and after the study was conducted. The collected data included results of interviews and observations, and secondary data (e.g., documents). The researchers transcribed the interviews and added information such as interview location, date, and time, also the informants' name, age, and job. Then, the researchers made a recap matrix of existing interview transcripts, outline, and theme categorization.

The data was analyzed by adopting the method used by Chariri (2009). For example, by understanding and examining the data which could be done by comparing or matching it with observational data (social life) and then interpreting the data. The data interpretation process included these following steps. First, the researchers selected only

Table 3 The biggest nutmegs producing areas in Maluku

\begin{tabular}{lllll}
\hline \multicolumn{1}{c}{ Ambon } & \multicolumn{4}{c}{ City/Regency } \\
\hline - Soya Village & - Morela Village & Saparua Island & Nusalaut Island & \multicolumn{1}{c}{ Banda Island } \\
- Hatalai Village & - Mamala Village & - Booi Village & - Titawai Village & - Lonthoir Village \\
- Naku Village & - Negeri Lima Village & & - Ameth Village & - Waer Village \\
- Hutumuri Village & - Seith Village & & - Nalahia Village & \\
& - Allang Village & & & \\
& - Liliboi Village & & & \\
& - Hatu Village & & & \\
&
\end{tabular}

Source: A study by Salampessy et al. (2013)

Table 4 Informants

\begin{tabular}{ccll}
\hline $\begin{array}{c}\text { Informant } \\
\text { (represented by initials) }\end{array}$ & $\begin{array}{c}\text { Age } \\
\text { (years) }\end{array}$ & & Job \\
\hline RP & 68 & Negeri (Village) government and farmer & Role \\
MW & 79 & Traditional leader and farmer & Data triangulation \\
CP & 73 & Farmer & Key informant \\
EH & 48 & Negeri (Village) government and farmer & Data triangulation \\
PH & 63 & Farmer & Key informant \\
EN & 51 & Farmer & Key informant \\
EH & 65 & Farmer & Key informant \\
LP & 77 & Community leader and farmer & Data triangulation \\
AP & 68 & Farmer & Key informant \\
AH & 62 & Farmer & Key informant \\
EP & 45 & Farmer & Key informant \\
\hline
\end{tabular}


necessary or important data (data reduction) to make it easy to interpret the data according to the research objectives. However, it did not eliminate the "unnecessary" data, but instead storing them and using them at the right time. Second, the researchers tried to understand and examine the data by comparing them with other data in detail. At this stage, the researchers used triangulation technique. It could be done by comparing the observational data with the interview data, what the informant said publicly with what was said privately, and the situation and perspective of the informant with the opinions of the people from various social classes (Raja, community leaders, and traditional leaders). Next, the researcher examined the data by comparing them with life or social reality. The interpretation results were then linked to the theoretical framework that had been established to minimize the bias. In addition, in the data interpretation process, the researchers also considered the events at the time of the study so that interpretation could be more detailed.

\section{Results and Discussion}

Saving habits Booi Village community had a cycle of planting, maintenance, harvesting nutmeg, and structured division of labor in the use of dusung. This cycle had been going on for generations as an effort to maintain the sustainability of the dusung, the mainstay of household life in Booi Village. The dusung was considered as an asset to support the community lives with nutmeg as the majority tree. However, people from outside the Booi Village often found illegally picked up nutmegs that had fallen on the ground. It is said illegal because the nutmegs fell on the ground were belonged to all members of the Booi community. This behavior had become such a habit and local wisdom. Field findings show that the habit of picking up nutmegs was also made by only certain individuals from outside the Booi Village. An informant from outside the Booi Village who the researchers met by accident revealed the reasons behind this phenomenon:

I was forced to pick the nutmegs that fell on the ground because household needs are increasing. Moreover, I have little kids, and some are still in school. I realized that I had violated the Booi (Village) territory, and I was often reprimanded by the Booi Villagers when we crossed paths in the dusung Waitua owned by the Booi Villagers (Zakarias, 57 years old, November 2016).

The information above shows that the presence of abundant nutmeg plants in Booi Village had become a "magnet" for people from the neighboring villages. The informant also understood the boundaries of the petuanan between his village and the Booi Village, for example, dusung waitua and Haria Village shares boundary area.

The results of the field study show that between Booi Village and neighboring villages (Haria Village and Paperu Village), there had never been any conflicts related to land boundaries. Geographically, the administrative area of the Booi Village government had a physical condition where it is hilly contrasted to the neighboring villages (Booi Village
Government, 2018). The Booi Village's petuanan area is approximately $11.4 \mathrm{~km}^{2}$, consisting of $6.8 \mathrm{~km}^{2}$ land and 4.6 $\mathrm{km}^{2}$ ocean with $5 \mathrm{~km}$ of coastline. The boundaries are as follows: The north is the petuanan village of Paperu, the south is Banda Sea; the west is the petuanan village of Haria, and the east is Booi Strait. The boundaries between the Booi Village area and the neighboring villages are identified through natural boundaries based on customary law, such as what had been revealed by the informant and a member of the Booi government:

The petuanan territory area with the Haria village is separated by Dusung Pelal (belongs to Amohorseja clan), Dusung Waitua (belongs to Hatusupy clan) and Dusung Wailatu (belongs to Lesilolo clan). Whereas the petuanan boundary with Paperu Village is separated by Dusung Telayo (belongs to Wenno-Taberima clan), Morteng Dusung (belongs to Wenno clan), Selano Dusung (belongs to Wenno clan) and Amahani Dusung (belongs to Nanulaitta clan) (Elly Hehanussa, April 2018)

To ensure the sustainability of nutmeg plantations, the Booi community had a habit of paduli pala (caring for gardens) in managing the dusung based on the knowledge they had passed down for generations. Due to pests and prolonged dry seasons, unproductive old and dry nutmeg trees are replaced with new trees.

Paduli pala activity consists of cleaning dusung, planting nutmeg trees, and harvest the nutmegs. This habit is considered effortless for the Booi Village community as it does not require huge costs and labor. The practice of paduli pala is one by replacing unproductive nutmeg trees with new nutmeg seeds. To get the new seeds, the local people walk down every nutmeg tree with fruits. Around the nutmeg tree, they found nutmeg seedlings and took them along with the soil around the nutmeg tree seedlings. It was done so that the seedlings did not wilt quickly and died when planted in a new place. A key informant stated that:

These new seedlings must be removed with this soil (while digging up the soil and seedlings). This method would make the nutmeg seeds flourish and vice versa, if I only took the nutmeg seedlings, then the seeds would wither quickly and die. Then, I have to calculate the right time to plant the seedlings (Petrus Hatusupy, October 2016)

The key informant's experience was one example where the Booi Village community had a "self-calculation" of a good time to plant a new nutmeg tree based on the season. Usually, December is the best season for planting nutmeg because it is a rainy month so that the newly planted nutmeg could get an adequate supply of water. The key informant explained that when planting nutmeg seedlings outside December, it must be watered regularly. However, it would be a challenge since the water source in Booi Village was 
quite far away.

The key informant also acknowledged that the Booi Village community had received assistance from the government in the form of nutmeg seeds. However, the nutmeg seeds were not evenly distributed. The community considered this to be unfair because they only paid attention to specific groups of people, while the people who were supposed to get assistance did not receive attention. The assistance provided also did not consider the correct planting time. The experience was again told by a key informant as follows:

We received help in the form of nutmeg seedlings, but only a few farmers received them. It was because Raja only paid attention to his family and group. We - who received this assistance - did not plant the nutmeg seeds as they were not from Booi Village. The timing of the distribution was incorrect, and the rent was very high (Petrus Hatusupy, October 2016)

The key informant said that his dusun is quite large, so he needed some workers to help him planting the nutmeg seedlings. The consequence was he had to give them high wages for paying labor. A worker was paid IDR250,000-IDR300,000 day ${ }^{-1}$, while the key informant needed 23 workers to help him so that the total cost that the informant must spend ranged from IDR250,000-IDR750,000. The high cost of the wage was what caused the key informants to refuse the seedlings provided by the government.

Besides the paduli pala actitivity, the Booi Village community also had a different habit of harvesting nutmeg from other communities on Saparua Island. In daily conversation, the Booi Village community called it "taking remnants of nutmeg" or paruru pala. They took the nutmeg remnants after the harvest period (between 24 weeks). It is done to meet the daily household needs when there are urgent needs.

The paruru pala starts at 78 a.m. They walked to the dusung for 40 minutes, depending on the dusung location. It was mostly done by men, but there were also women if their husbands were sick. After arriving in the dusung to do paruru pala, they did not immediately pick the nutmeg. They first performed a ritual of "kumpul api" around the nutmeg tree while they were taking a rest for a while. A key informant explained that the "kumpul api" had become a habit for every Booi Village community before starting activities in the village. It was done by burning the dry leaves they found around the nutmeg trees. The Booi community "believed" that it made every tree provided abundant harvests while keeping away wild animals during activities in the dusung.

The equipment to do paruru palu was simple. They only needed poles or sticks with a hook on it. In the local language, they called it "gai-gai" or "popar". The paruru pala started at the lowest to top, where they picked the red (ripe) nutmegs. The same process continued after they reached the topmost branch. As they were returning down, they also re-checked for the red nutmegs. The paruru pala was such a basic knowledge for the Booi Village community. Figure 3 picturizes the process.

A key informant explained that one day they could only pick less than ten nutmeg trees, and not all of them were ready. There were some nutmegs left until they were overripe so that they would fall to the ground and could be picked by anyone, including widows and orphans. The harvest of paruru pala was not as much as in the nutmeg season. Each tree is harvested variously, ranging from $23 \mathrm{~kg}$ of nutmegs, including the fuli (nutmeg flowers). He stated that although the harvest was not much, the Booi community was still able to meet their household needs by utilizing other various trees they planted in the dusung.

Empirical findings show that the Booi community
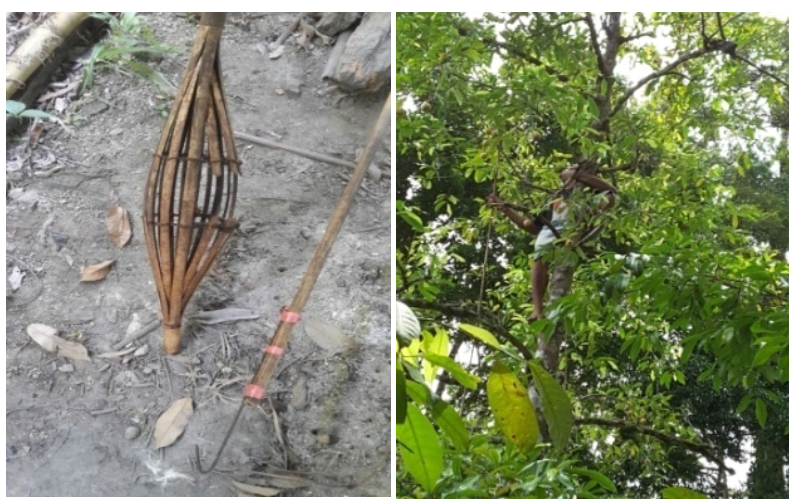

Source: Research documentation

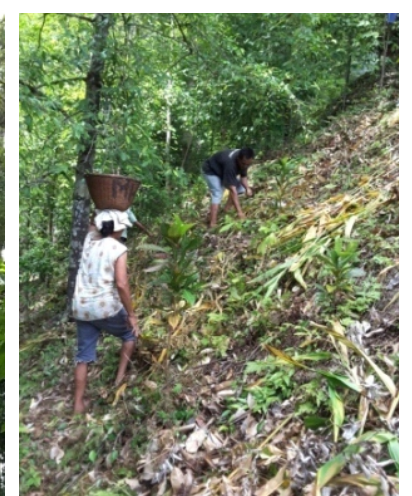

Figure 3 Nutmeg picker sticks and paruru pala activity.

\footnotetext{
'Paruru pala-a local term used by the Booi village community to pick up the nutmegs left on the tree on purpose. The word paruru consists of "par" and "uru". Par means to or heading to, while uru means head. Therefore, paruru means to the head in literal, or it can be defined as to pick nutmegs from the lowest to topmost branch.

${ }^{2}$ A simple and medium bamboo stick with a hook on it. Usually, the hook is made of part of the branch. Some are also made of bamboo, used to be a basket. It is
} $2.85 \mathrm{~m} 3.5 \mathrm{~m}$ long. 
combined short and long-life trees, such as cloves, durian, walnuts, coconut, and sago. Ownership of various trees was not the same, both in terms of area and number of trees. The key informant said that the habit of planting the nutmeg with other types of trees has been practiced for a long time.

The particular planting habit is an effort if the nutmeg harvest could not meet the household needs due to harvest failure or low prices. Therefore, the other trees, such as cloves, walnuts, coconut, sago, and mango, are planted to be substitutes. This study found that the Booi Village community also planted other trees, such as sweet potatoes and bananas, which they usually used for daily consumption. They rarely sold them to the market. A key informant stated that:

Afew months ago, there were a number of
household needs I could not meet due to
low nutmeg prices on the market. I had to
sell cassava, walnuts, and bananas to get
extra money (Paet Hein, March 2017)

The key informant admitted that he had sold bananas for IDR5,000-IDR10,000. He usually did not sell bananas and only had them for his family consumption. He had also sold walnuts at IDR50,000 $\mathrm{kg}^{-1}$ as an effort to meet the household needs.

Price expectation The increasing needs made Booi Village community learned to be careful in managing the nutmeg harvest so that they could meet their household needs. For the Booi Village community, losing nutmegs meant that they lost their lives. A key informant who was also a community leader explained that the nutmeg has the same value as money deposit in the bank. Therefore, whenever they need money, they can easily take it. Similarly, if there was an urgent need, then he could pick and sell the nutmeg harvest.

The Booi community had their way of anticipating various urgent needs with the nutmeg harvest they had. A key informant shared his experience where he had harvested four sacks of nutmegs, and only 2 or 3 sacks were sold to meet the household needs at the time. The rest would be used if there were other needs in the future. For example, to pay school tuition, medicine, and contribution to religious events.

The behavior of selling only parts of the total nutmeg harvest and storing them was due to the selling price, which tended to be dynamic and uncertain in the market. Sometimes, the key informants' estimates of the nutmeg price were not in line with their expectations. The desire to get additional income in the future made them get the lower prices. Moreover, the selling price of nutmeg and fuli (flowers) was highly dependent on the buyer. A key informant shared his experience:

We do not have any power to be able to bargain the prices with Chinese traders. We just follow their wishes, whatever the price they want, we accept it as long as we have the money right away. However, if other buyers could raise the price just a little, then surely, we would sell to these buyers. (Libreg Pattiasina, August 2018)
The above description shows that although the nutmeg price in other places (Ambon Island) was relatively higher, the key informant did not have a bargaining position with the buyer. The most important thing for them was to have the money so that their life could continue although the selling price was low. To anticipate the low selling price, the key informant would first sell the fuli. It was because the fuli required minimum one day to dry, and then the selling price could be higher. However, the nutmeg seeds could take up to 4 days to dry. If the weather was uncertain, the drying process could take up to seven days. This indicated that the opportunity to obtain cash to meet their household needs was getting smaller. Table 5 displays the selling price of nutmeg received by the farmers.

In 2013, one of the informants experienced a condition where the nutmeg seeds and flowers (fuli) was at its highest. However, it did not last long, and eventually, the price decreased to IDR $185,000 \mathrm{~kg}^{-1}$. As a result of these rapid changes, the informant had to think of other ways to meet his household sustainability. Generally, he would borrow some money or owe some necessities from his relatives or neighbors who owned a grocery stall. Within a week, he would pay them back. The other way to have more income is to sell wet nutmeg, although the selling price would be much lower.

Institutionalism and dependence on dusung and nutmeg trees The main common problems faced by rural communities in meeting their increasing and varied living needs were the risk of failure during the plantation process, uncertain selling prices, or limited access to plantation land use. These problems got worse as there was an economic crisis in Indonesia in 1998. About 17.28 million Indonesians lived in rural areas, and their lives were highly dependent on the agriculture and plantation sectors as a source of household livelihood.

In the government administration system in Indonesia, "dusung" is defined as part of a (small) village. This definition is different from what the Booi Village community understood. Dusung is defined as a plantation land managed and owned by a large family (house/clan), and there were long-life trees, one of them was nutmeg (Myristica fragrans). It was planted in most of the land and the main source of income for the Booi Village community. The total area of nutmeg plantation in Booi Village is $13 \mathrm{ha}$, with a total annual production of 10.5 ton. Rural communities (farmers)

Table 5 Selling price of nutmeg in farmer level

\begin{tabular}{ccc}
\hline \multirow{2}{*}{ Year } & \multicolumn{2}{c}{ Nutmeg price (IDR) } \\
\cline { 2 - 3 } & Seeds & Flowers $($ fuli) \\
\hline 2011 & 80,000 & 185,000 \\
2012 & 110,000 & 200,000 \\
2013 & 125,000 & 230,000 \\
2014 & 110,000 & 185,000 \\
2015 & 95,000 & 150,000 \\
2016 & 70,000 & 125,000 \\
2017 & 60,000 & 120,000 \\
2018 & 65,000 & 165,000 \\
\hline
\end{tabular}

Source: Research Result, 2018 
had the opportunity to strengthen their livelihoods by adopting agroforestry system (Reubens et al., 2011; Martin et al., 2016).

The traditional agroforestry system in Booi Village by combining various types of trees was inseparable from the local knowledge and experience to maintain their livelihoods. This knowledge and experience formed a "habit" in the Booi Village community's life. Types of plantation crops planted with the nutmeg crops are cloves, walnuts, coconut, sago, and mango (Table 2). As time went by, it developed into a rule in managing the dusung to this day. The local knowledge on the rural population awareness of the natural environment was traditional ecological knowledge (Berkes et al., 2000). For example, replacing unproductive nutmeg trees with nutmeg seedlings that grow around the parent tree, the "timing" to plant new nutmeg seedlings, and "kumpul api" rituals in beginning activities in the dusung. This field findings showed that the relationship between individuals and land was not limited to the use, ownership, or utilization but also a series of complex interactions between individuals and institutionalism (Lambin et al., 2003). For this reason, the habits and rules in managing the dusung in Booi Village can be considered to be institutional practices for the Booi community.

In line with findings by Lambin et al. (2003), a study by Nee (2005) showed that institutionalism is the major system (formal and informal), which are interconnected, and the basis for the community's economic behavior. For example, habits, shared beliefs, conventions, norms, and rules are the guideline of the actors for their actions when meeting their interests. They have been embedded in the lives of the Booi people, and they continue do it for generations, making it difficult to change. They manage the dusung based on their knowledge and experience. They assume the "habit" of managing the dusung has been done correctly and profitable. However, this phenomenon was an accumulation of risks that they must face with limited information.

The limited information was due to the inability of the Booi community to predict what would happen in the future as well as their lack of understanding in seeing the dusung environmental conditions. They were "afraid" of what would happen if they changed their habits. Moreover, to meet the household needs, they would prioritize or seek "safety" first. Therefore, they would always consider the profit and loss of each action they would take as an effort to maintain their livelihood. This value led them to only "following the existing rules" based on their habits and routines when facing the same previous situation. This behavior seemed to provide reinforcement that what happened in the past was an experience worth following.

The close relations among relatives in the Booi community also played a role, which made it difficult to change these habits. Studies conducted by Paavola and Adger (2006) showed that kinship provided various information access to resources for individuals and society. In this context, it had an important role as free information access on the village utilization based on experience. Therefore, they stuck to the old habit of managing the village, which had been believed to be true although it was monotonous. Thus, the above condition picturized the dependence of the Booi community on their rooted "habits" and simultaneously considered it as correct and logic, making it difficult to change what was believed in a short time although there was "new knowledge" that they could have obtained which was ways more profitable.

The dusung ownership between large families in Booi is different from one another. The average ownership of dusung range between $0.52 \mathrm{ha}$. There was a total area of 31.4 ha and nutmeg plantation area of 13 ha $(41.40 \%$ was nutmeg trees) (Pemerintah Desa Booi, 2018). The dusung ownership apply a patrilineal inheritance system. This system could not be understood merely as an economic aspect (homo economicus). However, the cultural and social aspects also playe a role in the forest ownership system. This was supported by field findings, which showed that the heirs did not only utilize the dusung for their interests, but other people could also have the same opportunities. It was reflected in the tradition of picking nutmeg seeds where other people, not the owner, could do it.

The empirical findings show that the natural capital in the form of dusung and nutmeg trees is such an asset for the Booi community to carry out their livelihood together. This livelihood asset is not only limited to natural capital in relation to the dusung ownership, but also to social capital. Studies by Woolcock (2000) and Weaver (2013) showed that strong group ties enable community members to have an awareness of group identity and grow a sense of togetherness to achieve common goals related to their economic welfare. In fact, the relationship created between the owner of the dusung and other people, whether they were family or not, is an example of social capital. This kinship is created through a long-time marriage relationship between members of the community. As a result, when there are relatives who have difficulties meeting their needs, then other family members will be willing to help. This was in line with a study by Adger (2003) and Paavola and Adger (2006), which confirm that kinship or family ties often help in overcoming economic problems.

Choice of household livelihood strategies in the Booi Village community Various efforts to overcome vulnerability through the use of dusung and nutmeg trees continued to be carried out by the Booi community to sustain household livelihoods. This livelihood strategy is related to how the community managed or combined their own and/or available livelihood assets to maintain their livelihood. A study by Scoones (2001) groups livelihood strategies into three parts, including intensification and extensification, diversification, and migration strategy. Empirical findings show the choices of livelihood strategies in the community in utilizing dusung and nutmeg trees, as follows:

Intensification and extensification strategy Intensification and extensification of agricultural resources are the main strategies in providing livelihood security (Dias et al., 2016). The agricultural intensification and extensification has several variations, including the use of dusung and home yards. It is done by planting more than one type of plant on the same dusung side by side with the nutmeg trees, such as cloves, walnuts, coconut, and sago. Whereas in the house 
yard, the community prefer to grow mango, banana, and cassava. Table 6 shows the level of tree production in Booi Village.

The land-use system by combining several types of plantation trees, as practiced by the Booi community, was known as agroforestry (Zomer et al., 2009; Rusinamhodzi et al., 2012). In this context, the authors see this behavior as land-use changes. They switch from planting nutmeg trees into/other types of trees due to a number of factors, for example, low nutmeg prices and tree failures due to pests. This is in line with studies by Lambin et al. (2003) and Hale et al. (2014). They revealed that it happens as there are opportunities created by the market, the pressure to increase the productivity of resources due to tree failure. The intensification and extensification strategies could provide better results and influence the amount of income (Brunelle et al., 2018). The livelihood strategy used by the Booi community aims to adapt to economic pressures and shocks, such as the low nutmeg price (seeds and flowers) and the risk of tree failure due to pests.

Diversification strategy Diversification is an effort to change the allocation of resources from one source of income to various sources of income in various sectors. In other words, diversification do not always depend on the agricultural sector. Three studies by Ellis (2000), Oktalina et al. (2015), and Saha and Bahal (2016) support this argument by finding that livelihood diversification is a survival strategy for rural households in developing countries. The dusung and nutmeg are the main sources of income for the Booi Village community, but they also kept trying to find opportunities for

Table 6 Level of tree production in Dusung of Booi Village community

\begin{tabular}{lc}
\hline \multicolumn{1}{c}{ Type of tree } & Production $\left(\right.$ ton year $\left.{ }^{-1}\right)$ \\
\hline Clove & 5.63 \\
Walnut & 4.80 \\
Coconut & 5.63 \\
Sago & 0.75 \\
Mango & 3.10 \\
\hline
\end{tabular}

Source: Statistics of Booi Village, 2018 their household income to change. Examples of diversification are doing business in the fisheries sector and waste of nutmeg fruit processing into candied nutmegs.

Nutmeg seeds holding strategy In this context, the nutmeg seeds-holding strategy is done by selling only parts of the harvest, and the rest will be sold when the harvest season ended, which was usually 13 weeks after the first batch as shown in Figure 4.

At this level, the author considere the nutmeg as money. The Booi community has several motives. First, precaution motive. The daily needs of the Booi community were various. The needs are predicted will be increased, opening a possibility of spontaneous and unexpected needs such as school books and college tuition of their kids in Ambon. This condition has frustated them. On the other hand, while they have to meet all their own household needs, they also need to provide for their children's needs. These needs are not planned. Therefore, the Booi community have to save their money for unpredictable events.

Second, speculative motive. This motive aims to gain motives in the future. The decision to hold or save some nutmegs temporarily is the impact of uncertainties and price expectations. For example, their expectations on better price changes. However, sometimes their expectation is not following what reality offered, and instead, they got lower prices compared to the results of previous sales.

Third, transaction motive. Meeting household needs and nutmeg price stability are problems for the Booi community. The desire to meet the increasing household needs is not always in line with nutmeg sales. Sometimes, the sales were not enough for them because the nutmeg price was too low, making them lack of cash. Therefore, they would prefer to owe their neighbors or relatives. These debts are usually paid by using "nutmeg" in the future.

The previously explained behavior show that the community had a variety of strategies to maintain their livelihoods from economic pressures and shocks, which are crucial issues for rural communities who depend their livelihoods on plantations and nutmeg trees.

Institutional impacts of sustainable livelihoods The livelihood strategy of the Booi community through the use of dusung and nutmeg is inseparable from social relations
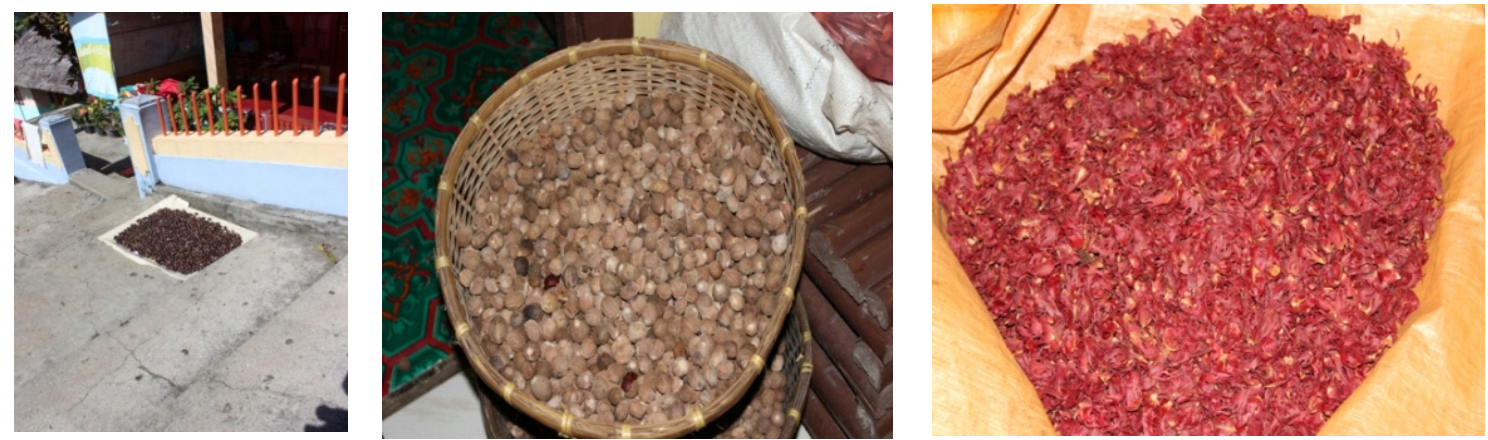

Source: Research documentation

Figure 4 Remaining nutmeg harvest that are kept or not sold temporarily. 
framed as "countryside kids." This context implies a sense of togetherness as fellow "native people" of Booi. This happen due to limited resources on the ownership and control of forests, including nutmeg as a source of their livelihoods. From a perspective of the community, fellowship and family had important and special places to one's involvement in a family characterized by a clan. This lead those who did not have land and nutmeg trees to be active in every forest in Booi territory. In other words, the household livelihood strategies in rural areas are embedded in the natural and socioeconomic context in which the community lived (Niemeijer \& Mazzucato, 2003; Peng et al., 2016).

In addition, this activity has become a habit in meeting their household needs based on rules and conventions in the Booi community. In this context, the rules (norms) and networks allow people to act together and even tend to strengthen the social relationship within their groups in maintaining their livelihoods (Caillois, 2004). These various dynamics indicate that there are efforts to meet the household needs of the community concerning the creation of livelihoods and only possible to happen when mutually agreed with rules and conventions. Therefore, it can be stated that this livelihood strategy will be continued as long as the institutionalism (traditions, customs, and rules) is well maintained.

Therefore, the authors believe that institutionalism (traditions, customs, and rules) have a significant impact on the livelihood strategies. The impacts are in the form of informal insurance access for those who do not have assets to be able to utilize the dusung and nutmeg trees. The access to these assets contributes to the sustainability of the household livelihoods of the Booi community as presented in the Figure 5.

\section{Conclusion}

The ability of rural communities to respond to challenges or vulnerabilities highly depends on local and institutional adaptations. This research reveals that in order to meet the life

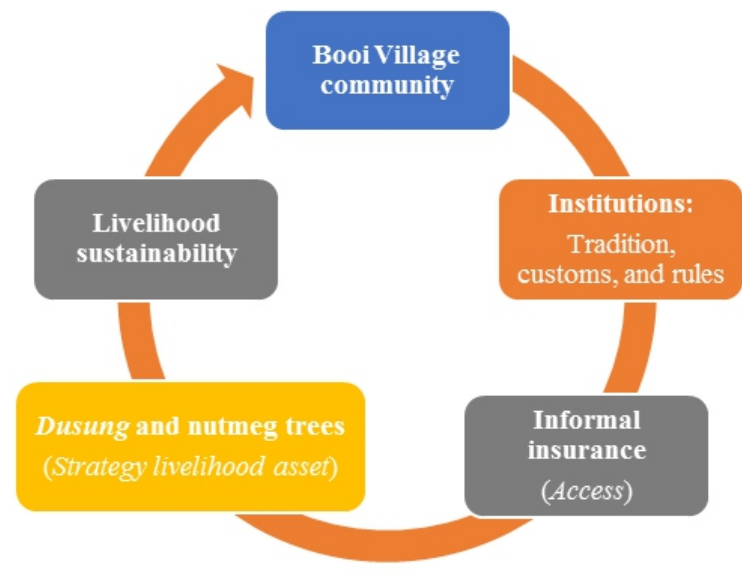

Figure 5 Flowchart of institutional impact on choice of livelihood strategies of Booi Village Community. needs, the Booi Village community employs various choices of livelihood strategies ranging from intensification and extensification, to diversification and nutmeg seed "holding" strategies. In addition, they also employ a barter system by paying their household needs using the nutmegs, either in the form of seeds or fruits. To ensure the sustainability of the community economy, access is also open to those without assets to utilize the dusung and nutmeg trees. These practices have been institutionalised and passed from generation to generation as an effort to deal with vulnerability and economic shocks.

\section{References}

Adger, W. N. (2003). Social capital, collective action, and adaptation to climate change. Economic Geography, 79(4), 387-404. Retrieved from https://www.jstor.org/ stable/30032945

Berkes, F., Colding, J., \& Folke, C. (2000). Rediscovery of traditional ecological knowledge as adaptive management. Journal of Ecological Applications, 10(5), 1251-1261. https://doi.org/10.1890/1051-0761(2000) 010[1251:ROTEKA]2.0.CO;2

Booi Village Government. (2018). Statistics of Booi Village.

[BPS] Badan Pusat Statistika Maluku Tengah. (2018). Kabupaten Maluku Tengah dalam angka 2018.

Brunelle, T., Dumas, P., Aoun, W. B., \& Gabrielle, B. (2018). Unravelling land-use change mechanisms at global and regional scales. BioPhysical Economics and Resource Quality, 3.https://doi.org/10.1007/s41247-018-0047-2

Budiono, R., Nugroho, B., Hardjanto, \& Nurrochmat, D. R. (2018). The village forest as a counter teritorialization by village communiities in Kampar Peninsula Riau. Jurnal Manajemen Hutan Tropika, 24(3), 115-125. https://doi.org/10.7226/jtfm.24.3.115

Caillois, J. M. (2004). Social capital and local economic development: For an application to French rural spaces. Journal of Regional and Urban Economics, 4(4), 551-578.

Chariri, A. (2009). Landasan filsafat dan metode penelitian kualitatif. Semarang: Laboratorium Pengembangan Akuntansi (LPA), Fakultas Ekonomi, Universitas Diponegoro.

Contreras, H. A., \& Fay, C. (2005). Strengthening forest management in Indonesia through land tenure reform: Issues and framework for action. Forest Trends. Retrieved from http://documents.worldbank.org/ curated/en/561471468197386518/Strengthening-forestmanagement-in-Indonesia-through-land-tenure-reformissues-and-framework-for-action

Creswell, J. W. (2010). Research design: Pendekatan kualitatif, kuantitatif dan mixed. Yogjakarta: PT Pustaka Pelajar. 
Dias, L. C. P., Pimenta, F. M., Santos, A. B., Costa, M. H., \& Ladle, R. J. (2016). Patterns of land use, extensification, and intensification of Brazilian agriculture. Global Change Biology, 22(8), 2887-2903. https://doi.org/10. $1111 /$ gcb. 13314

Ellis, F. (2000). Rural livelihoods and diversity in developing countries. Oxford: Oxford University Press.

Hale, I. L., Wollheim, W. M., Smith, R. G., Asbjornsen, H., Brito, A. F., Broders, K., ..., \& Rowe, R. (2014). A scaleexplicit framework for conceptualizing the environmental impacts of agricultural land use changes. Journal in Sustainability, 6(12), 8432-8451. https://doi.org/10.3390/su6128432

Jose, S. (2009). Agroforestry for ecosystem services and environmental benefits: An overview. Agroforestry Systems, 76, 1-10. https://doi.org/10.1007/s10457-0099229-7

Khatiwada, S. P., Deng, W., Paudel, B., Khatiwada, J. R., Zhang, J., \& Su, Y. (2017). Household livelihood strategies and implication for poverty reduction in rural areas of Central Nepal. Sustainability, 9(4), 612. https://doi.org/10.3390/su9040612

Kherallah, M., \& Kirsten, J. F. (2001). The new institutional economics: Application for agricultural policy research in developing countries. Journal Agrekon, 41(2), 110-133. https://doi.org/10.1080/03031853.2002. 9523589

[KPDT] Kementerian Pembangunan Daerah Tertinggal. (2017). Peraturan Direktorat Jenderal Pembangunan Daerah Tertinggal Nomor 126 Tahun 2017 tentang Penetapan prioritas sasaran pembangunan, pembangunan daerah tertinggal, dan transmigrasi. Jakarta: Kementerian Pembangunan Daerah Tertinggal.

Lambin, E. F., Geist, H. J., \& Lepers, E. (2003). Dynamics of land-use and land-cover change in tropical regions. Annual Review Environment Resources, 28(1), 205-241. https://doi.org/10.1146/annurev.energy.28.050302.1054 59

Martin, E., Suharjito, D., Darusman, D., Sunito, S., \& Winarno, B. (2016). Etika subsistensi petani kopi: Memahami dinamika pengembangan agroforestri di dataran tinggi Sumatera Selatan. Jurnal Sodality IPB Bogor, 4(1). https://doi.org/10.22500/sodality.v4i1. 14410

Mehta, L., Leach, M., Newell, P., Scoones, I., Sivaramakrishnan, K., \& Way, S. A. (1999). Exploring understandings of institutions and uncertainty: New directions in natural resource management. Retrieved from https://opendocs.ids.ac.uk/opendocs/handle/ $20.500 .12413 / 13858$

Miettinen, J., Shi, C. \& Liew, S. C. (2011). Deforestation rates in insular Southeast Asia between 2000 and 2010. Global Change Biology, 17, 2261-2270. https://doi.org/ 10.1111/j.1365-2486.2011.02398.x

Muttaqin, M. Z. (2013). Pengelolaan lahan dan hutan di Indonesia: Akses masyarakat lokal ke sumberdaya hutan dan pengaruhnya pada pembayaran jasa lingkungan. Jakarta: Badan Penelitian dan Pengembangan Kehutanan Pusat Penelitian dan Pengembangan Perubahan Iklim dan Kebijakan, Kementerian Kehutanan.

Napitu, J, P., Hidayat, A., \& Basuni, S., \& Sjaf, S. (2017). Conflict of utilization and sustainable production forest management in forest management unit of meranti in South Sumatera. Jurnal Manajemen Hutan Tropika, 23(3), 158-170. https://doi.org/10.7226/jtfm.23.3.158

Nee, V. (2005). The new institutionalism in economics and sociology. In Smelser, S., Swedberg, R., eds., The Handbook of Economic Sociology. New Jersey: Princeton University Press.

Niemeijer, D., \& Mazzucato, V. (2003). Moving beyond indigenous soil taxonomies: Local theories of soils for sustainable development. Geoderma, 111(34), 403-424. https://doi.org/10.1016/S0016-7061(02)00274-4

North, D. C. (1990). Institutions, institutional change and economic performance. Cambridge: Cambridge University Press.

Nugrohowardhani, R. L. K. R. (2016). Sabana Sumba: Kelembagaan dan pembangunan ekonomi [dissertation]. Salatiga: Universitas Kristen Satya Wacana.

Oktalina, S. N., Awang, S. A., Suryanto, P., \& Hartono, S (2015). Strategi petani hutan rakyat dan kontribusinya terhadap penghidupan di Kabupaten Gunung Kidul. Kawistara, 5(3), 221-328. Retrieved from https://dev.jurnal.ugm.ac.id/kawistara/article/download/ $10058 / 7566$

Paavola, J., \& Adger, W. N. (2006). Fair adaptation to climate change. Ecological Economics, 56, 594-609. https://doi.org/10.1016/j.ecolecon.2005.03.015

Peng, W., Zheng, H., Robinson, B. E., Li, C, \& Wang, F. (2016). Household livelihood strategy choices, impact factors, and environmental consequences in Miyun Reservoir Watershed, China. Sustainability, 9(2), 175. https://doi.org/10.3390/su9020175

Reubens, B., Moeremans, C., Poesen, J., Nyssen, J., Tewoldeberhan, S., Franzel, S., \& Muys, B. (2011). Tree species selection for land rehabilitation in Ethiopia: From fragmented knowledge to an integrated multi-criteria decision approach. Agroforestry Systems, 82, 303-330. https://doi.org/10.1007/s10457-011-9381-8

Rusinamhodzi, L., Corbeels, M., Nyamagara, J., \& Giller, K. E. (2012). Maize-grain legume intertreeping is an attractive option for ecological intensification that 
reduces climatic risk for smallholder farmers in central Mozambique. Field Crop Research, 136, 12-22. https://doi.org/10.1016/j.fcr.2012.07.014

Rutherford, M. (2001). Institutional economics: Then and now. The Journal of Economic Perspectives, 15(3), 173-194. https://doi.org/10.1257/jep.15.3.173

Saha, B., \& Bahal, R. (2016). Livelihood diversification pursued by farmers in West Bengal. Indian Research Journal of Extension Education, 10(2). Retrieved from https://pdfs.semanticscholar.org/a568/7e421df27705f47 01f7aa591f41fcb046006.pdf

Salampessy, M. L., Bone, I., \& Febryano, I. G. (2012). Performasi dusung pala sebagai salah satu agroforestri tradisional di Maluku. Tengkawan: Jurnal Ilmu Kehutanan, 2(2), 55-65. https://doi.org/10.26418/ jt.v2i2.1941

Scoones, I. (2001). Sustainable rural livelihoods: A framework for analysis. Institute of Development Studies Working Paper 72, Bringhton: IDS. Retrieved from http://opendocs.ids.ac.uk/opendocs/bitstream/handle/12 $3456789 / 3390 / \mathrm{Wp} 72$.pdf? sequence $=1$

Walelign, S. Z. (2016). Livelihood strategies, environmental dependency and rural poverty: The case of two villages in rural Mozambique. Environment Development and Sustainability, 18(2), 593-613. https://doi.org/10.1007/ s10668-015-9658-6

Wattimena, G. A. (2003). Agroforesti di Maluku. Prosiding PERMANA, 1(1), 213-224. Retrieved from https://ejournal.unpatti.ac.id/ppr_paperinfo_lnk.php?id $=278$

Weaver, R. D., McMurphy, S. M., \& Habibov, N. N. (2013). Analyzing the impact of bonding and bridging social capital on economic well-being: Results from Canada's general social survey. Sociological Spectrum, 33, 566-583. https://doi.org/10.1080/02732173.2013. 836149

Wollenberg, E., Belcher, B., Sheil, D., Dewi, S., \& Moeliono, M. (2004). Why are forest areas relevant to reducing poverty in Indonesia? Governance Brief. Bogor: CIFOR. Retrived from https://www.jstor.org/ stable/resrep01828

Woolcock, M. (2000). Social capital and economic development: Toward a theoretical synthesis and policy framework. Theory and Society, 27(1), 151-208. Retrieved from https://www.jstor.org/stable/657866

Wulandari, P. S. (2017). Strategi penghidupan berkelanjutan masyarakat petani berbasis aset (Kasus di Dusun Sumberawan, Toyomarto, Kecamatan Singosari, Kabupaten Malang) [thesis]. Malang: Universitas Brawijaya.

Yizengaw, Y. S., Okoyo, E. N., \& Beyene, F. (2015). Determinants of livelihood diversification strategies: The case of smallholder rural farm households in Debre Elias Woreda, East Gojjam Zone, Ethiopia. African Journal of Agricultural Research, 10(19), 1998-2013. https://doi.org/10.5897/AJAR2014.9192

Young, M. D., \& Solbrig, O. T. (1992). Savanna management for ecological sustainability, economic profit and social equity. Retrieved from http://hdl.handle.net/102.100. $100 / 247486$ ? index $=1$

Zomer, R. J., Trabucco, A., Coe, R., \& Place, F. (2009). Trees on farm: Analysis of global extent and geographical patterns of agroforestry. ICRAF Working Paper No. 89. Nairobi, Kenya: World Agroforestry Center. Retrieved from https://www.researchgate.net/publication/ 281748825_Trees_on_farm_analysis_of_global_extent _and_geographical_patterns_of_agroforestry 